\section{Public health implications}

- Women from socioeconomically deprived areas have significantly poorer survival from breast cancer than women from affluent areas

- In this population based study we investigated the relation between socioeconomic deprivation and the prognostic factors tumour size, axillary lymph node status, histological grade, and oestrogen receptor concentration

- Socioeconomic deprivation was not significantly related to tumour stage or biology

- Other possible explanations for survival differences, such as differences in breast cancer treatment or in host response, should be investigated

- If the reasons for socioeconomic differences in survival could be identified and eliminated a greater number of lives could be saved than that expected from the national breast screening programme currently invited for screening. Socioeconomic differences in survival from breast cancer therefore have important implications for public health.

We thank Dr R Leake, Department of Biochemistry, University of Glasgow, for supplying data on oestrogen receptor concentration.

1 Tomatis L, ed. Cancer: causes, occurrence and control. Lyons: IARC Scientific Publications, 1990. (No 100.)

2 Karjalainen S, Pukkala E. Social class as a prognostic factor in breast cancer survival. Cancer 1990;66:819-26.

3 Vagero D, Persson G. Cancer survival and social class in Sweden. 9 Epidemiol Community Health 1987;41:204-9.

4 Gordon NH, Crowe JP, Brumberg DJ, Berger NA. Socioeconomic factors and Gordon NH, Crowe JP, Brumberg DJ, Berger NA. Socioeconomic factors and
race in breast cancer recurrence and survival. Am $\mathcal{G}$ Epidemiol 1992;135: race in $609-18$.

5 Kogevinas M, Marmot MG, Fox AJ, Goldblatt PO. Socioeconomic differences in cancer survival. $f$ Epidemiol Community Health 1991;45:216-9.

$6 \mathrm{Keirn} W$, Metter $G$. Survival of cancer patients by economic status in a free care setting. Cancer 1985;55:1552-5.

7 Vernon SW, Tilley BC, Neale AV, Steinfeldt L. Ethnicity, survival, and delay in seeking treatment for symptoms of breast cancer. Cancer 1985;55: 1563-71.

8 Carstairs V, Morris R. Deprivation and Health in Scotland. Aberdeen: Aberdeen University Press, 1991.

9 Mohla S, Sampson CC, Khan T, Enterline JP, Leffall L Jr, White JE. Estrogen and progesterone receptors in breast cancer in black Americans: correlation of receptor data with tumour differentiation. Cancer 1982;50: 552-9.

10 Natarajan N, Nemoto T, Mettlin C, Murphy GP. Race-related differences in breast cancer patients. Results of the 1982 national survey of breast cancer breast cancer patients. Results of the 1982 national survey of

11 Ownby HE, Frederick J, Russo J, Brooks SC, Swanson GM, Heppner GH, et al. Radical differences in breast cancer patients. If Natl Cancer Inst 1985;75:55-60.

12 Coates RJ, Bransfield DD, Wesley M, Hankey B, Eley JW, Greenberg RS, $e t$ al. Differences between black and white women with breast cancer in time from symptom recognition to medical consultation. Black/White Cancer Survival Study Group. I Natl Cancer Inst 1992;84:938-50.

13 Mittra I, MacRae KD. A meta-analysis of reported correlations between prognostic factors in breast cancer: does axillary lymph node metastasis represent biology or chronology? Eur F Cancer 1991;27:1583-9.

14 Intemational Union Against Cancer. TNM classification of malignant tumours. Geneva: UICC, 1987.

15 Bloom HJG, Richardson WW. Histological grading and prognosis in breast cancer. Br $\%$ Cancer 1957;11:359-77.

16 Elston CW, Ellis IO. Pathological prognostic factors in breast cancer. I. The value of histological grade in breast cancer: experience from a large study with long-term follow-up. Histopathology 1991;19:403-10.

17 Farley TA, Flannery JT. Late-stage diagnosis of breast cancer in women of lower socioeconomic status: public health implications. Am f Public Health 1989;79:1508-12.

18 Mandelblatt J, Andrews H, Kerner J, Zauber A, Burnett W. Determinants of late stage diagnosis of breast and cervical cancer: the impact of age, race, social class, and hospital type. Am f Public Health 1991;81:646-9.

19 Wells BL, Horm JW. Stage at diagnosis in breast cancer: race and socioeconomic factors. Am f Public Health 1992;82:1383-5.

20 Richardson J, Langholz B, Bernstein L, Burciaga C, Danley K. Ross RK. Stage and delay in breast cancer diagnosis by race, socioeconomic status, age and year. Br $\mathcal{\text { C Cancer 1992;65:922-6. }}$.

21 Ayanian JZ, Kohler BA, Abe T, Epstein AM. The relation between health insurance coverage and clinical outcomes among women with breast cancer. insurance coverage and clinical
$N$ Engl f Med 1993;329:326-31. deprivation category could be eliminated so that al women had the five year survival rate of the most affluent group, 475 more women in the West of Scotland could be expected to survive for five years. This would also benefit women outside the age group
22 NHS Breast Screening Programme. Breast cancer screening in 1990: evidence and experience since the Forrest Report. Sheffield: NHSBSP, 1991.

(Accepted 19 August 1994)

\section{Driving, glaucoma, and the law}

\section{T Potamitis, R K Aggarwal, $M$ Tsaloumas, C Rene, J McLaughlin, E O'Neill}

The Road Traffic Act 1988 requires drivers to inform the Driver and Vehicle Licensing Agency of any disability or condition that affects their fitness to drive or which might do so in the future.

Glaucoma clearly falls within this definition and must therefore be reported to the agency regardless of the degree of visual loss. Failure to do so renders the patient liable to prosecution. We assessed the awareness of this legal obligation among patients with glaucoma attending our hospital and among British ophthalmologists.

\section{Subjects, methods, and results}

A total of 186 patients ( 98 men and 88 women) attending routine appointments at the glaucoma department of our hospital during November 1992 were interviewed by the examining clinician. Eighty five were drivers. The mean age of the drivers $(65.5$ years, age range 24 to 83 ) was slightly lower than that of those who did not drive ( 71.5 years, age range 24 to 90 years). Sixty one of the male patients were drivers compared with only 24 of the female patients.

Reassurance was given that the interview was confidential. The clinician recorded the information on a standard form. After the interview patients were advised to inform the Driver and Vehicle Licensing Agency of their diagnosis; if their visual performance did not achieve the minimum legal requirement for driving they were advised to refrain from driving. The table summarises the results.

Multiple choice questionnaires were posted to 450 consultant ophthalmologists in the United Kingdom, their names and addresses having been obtained from the mailing list of an ophthalmological pharmaceutical company. To encourage replies a stamped addressed envelope was included. Of the 450 questionnaires posted in January 1993, $336(75 \%)$ were completed and returned by the 30 April 1993, the end of the study. The replies are summarised in the table. 
Awareness of law on reporting glaucoma to Driver and Vehicle Licensing Agency among patients with glaucoma and among ophthalmologists

\begin{tabular}{|c|c|}
\hline & $\begin{array}{l}\text { No of } \\
\text { responses }\end{array}$ \\
\hline \multicolumn{2}{|l|}{ Patients'survey } \\
\hline Total No of drivers & 85 \\
\hline \multicolumn{2}{|l|}{$\begin{array}{l}\text { Have you informed the Driver and Vehicle Licensing Agency } \\
\text { that you are driving? }\end{array}$} \\
\hline No & 71 \\
\hline \multicolumn{2}{|l|}{ Are you aware of the legal obligation to do so? } \\
\hline No & 65 \\
\hline \multicolumn{2}{|l|}{ Ophthalmologists'survey } \\
\hline Total No of replies & 336 \\
\hline \multicolumn{2}{|l|}{ Do you ask your patients with glaucoma if they drive? } \\
\hline $\begin{array}{l}\text { Only when they have extensive visual loss, rendering them } \\
\text { visually unfit for driving }\end{array}$ & 261 \\
\hline Only if glaucoma is newly diagnosed & 21 \\
\hline Seldom & 48 \\
\hline No reply & 6 \\
\hline \multicolumn{2}{|l|}{$\begin{array}{l}\text { Do you discuss with your patients with glaucoma the legal } \\
\text { requirements that must be fulfilled for them to drive? }\end{array}$} \\
\hline $\begin{array}{l}\text { Only when they have extensive visual loss, rendering them } \\
\text { visually unfit for driving }\end{array}$ & 274 \\
\hline Only if glaucoma is newly diagnosed & 17 \\
\hline Seldom & 42 \\
\hline No reply & 3 \\
\hline \multicolumn{2}{|l|}{$\begin{array}{l}\text { To your knowledge, patients with glaucoma have a legal } \\
\text { requirement to inform the Driver and Vehicle Licensing } \\
\text { Agency of their diagnosis: }\end{array}$} \\
\hline Regardless of their visual fields or acuity & 174 \\
\hline Only when they have any field loss & 86 \\
\hline $\begin{array}{l}\text { Only when they have extensive visual loss, rendering them } \\
\text { visually unfit for driving }\end{array}$ & 68 \\
\hline No reply & 8 \\
\hline
\end{tabular}

\section{Comment}

Visual fitness to drive is in itself a complex concept, and the wide range of visual standards required by different countries ${ }^{1}$ reflects this. Whether it is reasonable for all patients with glaucoma to inform the Driver and Vehicle Licensing Agency of their diagnosis even when they have no visual loss, is debatable. With 35 million driving licence holders in the United Kingdom alone (Driver and Vehicle Licensing Agency, unpublished data), reporting all cases of a condition as prevalent as glaucoma ${ }^{2}$ would no doubt create a substantial amount of work, for both the agency and ophthalmologists. The law, however, is quite clear in its requirements.

When patients' visual loss is severe most ophthalmologists do ask whether they drive, but glaucoma is notifiable irrespective of the state of vision. A proportion of ophthalmologists seldom discuss the subject of driving with their patients who have glaucoma, and this perhaps reflects the fact that almost half of them were not aware of the current legal requirements.

Most patients had not informed the Driver and Vehicle Licensing Agency of their diagnosis, and a large proportion were unaware of the legal obligation to do so. Clearly, not enough information about this subject is reaching patients. We found that none of the standard information booklets on glaucoma advises patients on the law. The International Glaucoma Association does remind its members in its newsletters of the need to inform the Driver and Vehicle Licensing Agency if they continue to drive, but unfortunately not all patients with glaucoma are members.

Although physicians are not legally obliged to inform their patients of their statutory duties, they are ideally placed to offer advice on this matter and should ensure that they are aware of any changes in the law.

Drivers Medical Unit, Driver and Vehicle Licensing Agency, Swansea SA99 1TA Margaret Hawkins, medical adviser

\section{Commentary: Patients and doctors risk prosecution if they do not uphold the law}

\section{Margaret Hawkins}

Section 92 of the Road Traffic Act 1988 defines prescribed, relevant, and prospective disabilities. All three categories may include glaucoma. Prescribed disabilities bar people from driving. Relevant disabilities are prescribed disabilities plus any disorder that renders a person a source of danger while driving. Because of their progressive or intermittent nature prospective disabilities may lead to the development of a prescribed or relevant disability. When a prospective disability is confirmed a licence may be issued only subject to a medical review after one, two, or three years.

All drivers must be able to read in good daylight (with glasses or contact lenses if worn) a motor vehicle number plate $20.5 \mathrm{~m}$ away with symbols $79.4 \mathrm{~mm}$ high. (Paragraph 21 (1) (c) 1987 Motor Vehicles (Driving Licences Regulations)). This visual standard approximates to a theoretical $6 / 10$ on the Snellen chart, but in practice ability to perform the test is variable and visual acuity is not necessarily indicative of the person's ability to satisfy the legal requirement.

The minimum standard of visual field for safe driving is at least $120^{\circ}$ on the horizontal measured by the Goldmann perimeter (or equivalent) and $20^{\circ}$ above or below the horizontal from fixation in any meridian. This was defined by the College of Ophthalmologists in response to a second European Commission directive (L237/2091), but it is not yet statutory.

The legal requirement for group 2 drivers (large goods vehicles or passenger carrying vehicles) is higher than for ordinary drivers. These drivers must have a minimal visual acuity of $6 / 9$ in the better eye and $6 / 12$ in the other eye (uncorrected not less than 3/60 in each eye). In addition, they must have a full visual field with no diplopia. Monocularity is a bar. "Grandfather rights" apply to drivers who held their group 2 licences before 1 January 1983. Other drivers may also be affected. Further information may be obtained from the Drivers Medical Unit.

People with glaucoma at whatever stage must, therefore, notify the Drivers Medical Unit at the Driver and Vehicle Licensing Agency. Although notification is the responsibility of licence holders, their doctor may do so without their consent if it is in the public interest to do so. If there is any doubt doctors are advised to consult their medical defence society.

There are bound to be circumstances in which licence holders are not aware that their medical condition is likely to affect safe driving. It is therefore most important that doctors are aware of the law and the national medical guidelines. Failure to advise their patients correctly may render doctors liable to litigation should an accident occur. Any doctor who has not received a copy of At a Glance Guide to Current Medical Standards of Fitness to Drive, published in August this year, is advised to telephone the Drivers Medical Unit (0792 783686). A copy will be sent free of charge. Medical Aspects of Fitness to Drive was last published in 1985 , and a new edition is currently being prepared.

The Drivers Medical Unit is aware that many people have not reported glaucoma and other disabilities as required by law. These licence holders risk prosecution, and should an accident occur their insurance would be void. The above legislation is in the interests of road safety.

1 Raffle A, ed. Medical aspects of fimess to drive. London: HMSO, 1985
1 North RV. The relationship between the extent of visual field and driving performance-a review. Ophthalmic Physiol Opt 1985;5:205-10.

Kini MM, Leibowitz HM, Colton J, Nickerson RJ, Ganley J, Dawber TR Prevalence of senile cataract, diabetic retinopathy and open angle glaucoma in

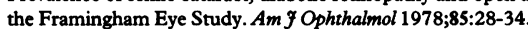

